PKn Progresif, Vol. 14 No. 2 Desember 2019

\title{
PENGUATAN KARAKTER KEWARGANEGARAAN DI SMP MURNI 1 SURAKARTA MELALUI PEMBELAJARAN PPKN.
}

\author{
Faizah Nur Diana \\ Prodi PPKn FKIP Universitas Sebelas Maret Surakarta \\ Email: diana.dn584@gmail.com \\ Winarno \\ Universitas Sebelas Maret Surakarta \\ Email: winarnonarmoatmojo@staff.uns.ac.id \\ Moh. Muchtarom \\ Universitas Sebelas Maret Surakarta \\ Email: muhtarom1974@gmail.com
}

\begin{abstract}
ABSTRAK
Tujuan Penelitian ini adalah untuk (1) Mengetahui implementasi penguatan karakter kewarganegaraan di SMP Murni 1 Surakarta melalui pembelajaran PPKn dan (2) Mengetahui hambatan dalam proses penguatan karakter kewarganegaraan di SMP Murni 1 Surakarta melaui pembelajaran PPKn. Penelitian ini menggunakan metode kualitatif, karena penelitian ini tidak membuktikan atau menolak suatu hipotesis akan tetapi data yang diolah di deskriptifkan dan lebih menekankan makna dari pada generalisasi. Teknik pengambilan sampel yang digunakan dalam penelitian ini yaitu purposive sampling. Teknik pengumpulan data melalui wawancara, observasi, dan studi dokumen. Validitas data dalam penelitian ini menggunakan triangulasi data yaitu triangulasi data dan metode. Analisis data yang digunakan dalam penelitian ini adalah dengan model Milles dan Huberman yaitu reduksi data, penyajian data dan penarikan kesimpulan. Hasil penelitian menunjukan bahwa (1) Guru merancang RPP dengan memasukkan nilai-nilai karakter dalampembelajaran PPKn sebagai bentuk penguatan karakter kewarganegaraan, melakukan penguatan secara verbal dan non verbal baik dalam pembelajaran di kelas maupun di luar kelas, melakukan home visit untuk melihat lingkungan sekitar peserta didik, (2) Hambatan yang dihadapi oleh guru yaitu tidak adanya dukungan dari orang tua karena tidak memperdulikan perkembangan peserta didik, faktor ekonomi keluarga yang membuat peserta didik mempunyai sifat mudah membangkang karena keinginannya tidak terpenuhi, lingkungan tenpat tinggal peserta didik yang terkesan lingkungan kurang baik, dan peserta didik yang tidak kondusif pada saat pembelajaran di kelas.
\end{abstract}

Kata kunci: penguatan, karakter kewarganegaraan, pembelajaran 
17 Faizah Nur Diana: penguatan karakter kewarganegaraa di SMP Murni 1 ...

\begin{abstract}
The purpose of this study was to (1) Understand the implementation of strengthening civic disposition in SMP Murni 1 Surakarta through civic education learning and (2) Understand the barriers in the process of strengthening civic disposition at SMP Murni 1 Surakarta through civic education learning.

This study used a qualitative method because this research did not prove or reject a hypothesis, but the data processed was descriptive and emphasized the meaning rather than generalization. The sampling technique used in this study was purposive sampling. Data collection techniques were interviews, observations, and documents analysis. The validity of the data in this study used data triangulation, namely, data and methods triangulation. Analysis of the data used in this study was the Milles and Huberman model, namely data reduction, data presentation, and conclusion drawing.

The results showed that (1) The teacher designed the lesson plan by including character values in the civic education learning as a form of strengthening civic disposition, strengthening verbally and non-verbally both in learning in the classroom and outside the classroom, conducting a home visit to see the environment around students, (2) Barriers faced by teachers were the lack of support from parents because they did not care about the development of students, family economic factors that made students defiant because their desires were not fulfilled, the environment about the lives of students that seemed unfavorable environment, and students who were not conducive when learning in class.
\end{abstract}

Keywords: reinforcement, civic disposition, learning 


\section{PENDAHULUAN}

Pendidikan nasional, bdrtujuan untuk membentuk peserta didik yang cerdas dan terampil. Selain itu, pendidikan nasional juga membenuk watak serta membangun peradaban bangsa yang bermartabat dalam rangka mencerdaskan kehidupan bangsa seperti yang tertuang pada Pembukaan UUD 1945 alenia k3-4. Sebagaimana yang diamanatkan UU Sisdiknas No 20 tahun 2003, pendidikan bertujuan untuk membangun insan yang berbudi luhur. Pendidikan yang bermartabat, bertujuan untuk mengembangkan potensi peserta didik agar menjadi manusia yang beriman dan bertaqwa kepada Tuhan YME.

Di dalam Desain Induk Pengembangan Karakter Bangsa (Pangalila, 2017: 91), ditegaskan bahwa semua permasalahan yang dihadapi bangsa Indonesia ini mengalami "ketidakpastian jati diri dan karakter bangsa yang bermuara pada: (1) disorientasi dan belum dihayatinya nilai-nilai Pancasila sebagai filosofi dan ideologi bangsa, (2) keterbatasan perangkat kebijakan terpadu dalam mewujudkan nilai-nilai esensi Pancasila, (3) bergesernya nilai etika dalam kehidupan berbangsa dan bernegara, (4) memudarnya kesadaran terhadap nilai-nila budaya bangsa, (5) ancaman disintegrasi bangsa, dan (6) melemahnya kemandirian bangsa".

Arus globalisasi yang terjadi saat ini, menyebabkan munculnya gaya hidup individualistis yang mengutamakan kepentingan diri sendiri, dan berdampak pada kesetiakawanan sosial semakin hilang, contohnya saat terjadi musibah, kecelakaan dan sakit hanya sedikit orang yang empati (Indratmoko, 2017: 124). "Demoralisasi ini karena proses pembelajaran cenderung mengajarkan pendidikan moral dan budi pekerti yang sebatas tekstual dan teoritis" (Zubaedi, 2011: 5). Seperti yang dikemukakan Lickona (2013: 7) "Berdasarkan penelitian sejarah dari seluruh negara di dunia ini, pada dasarnya pendidikan memiliki dua tujuan, yaitu membimbing para pembelajar untuk menjadi cerdas dan memiliki perilak berbudi”.

Pendidikan karakter merupakan upaya untuk meningatkan "mutu proses dan hasil pendidikan yang mengarah pada pendidikan karakter dan akhlak mulia pembelajar secara utuh, terpadu, dan seimbang, sesuai dengan standar kompetensi lulusan pada setiap satuan pendidikan" (Ramdhani, 2014: 30). Sebagai upaya program pendidikan yang amat strategis bagi upaya pendidikan karakter, "PKn merupakan salah satu instrumen fundamental dalam bingkai pendidikan nasional sebagai media bagi pembentukan karakter bangs (nation and character building) di tengah heterogenitas dan pluralisme yang menjadi karakteristik utama bangsa Indonesia" (Zuriah, 2012: 170). 
Pendidikan karakter merupakan salah satu misi yang diemban di dalam pembelajaran Pendidikan Pancasila dan Kewarganegaraan agar peserta didik mampu menanamkan kebiasaan tentang mana yang baik dan tidak baik. Misi lain dari PPKn adalah (Cholisin, 2011:2) "pendidikan politik/pendidikan demokrasi, pendidikan hukum, pendidikan HAM, dan bahkan sebagai pendidikan anti korupsi”. Penelitian terkait juga dilakukan oleh mahasiswa UNY dengan mengambil objek di MTs Ali Maksum pada bulan April sampai Juni 2014 dengan hasil implementasi PPKn dalam pembentukan karakter kebangsaan peserta didik menunjukkan adanya dampak positif terhadap nilai-nilai karakter yang ditanamkan. "Meskipun, dalam pembentukan karakter kebangsaan belum mendapat perhatian khusus baik dari guru PPKn maupun dari pihak sekolah".

Penelitian juga dilakukan oleh Rusmiati mengenai peran guru PPKn dalam mendorong peserta didik menjadi pribadi yang berkarakter dan hasilnya bahwa sebanyak 32 peserta didik menjawab guru mempunyai peranan penting unuk mendorong peserta didik yang berkarakter baik, di lingkungan sekolah maupun di luar lingkungan sekolah (Rusmiani, 2018: 85). Melalui Pendidikan Pancasila dan Kewaganegaraan, diharapkan peserta didik dibekali dengan pengetahuan-pengetahuan moral yang sesuai dengan nilai-nilai Pancasila dan UUD 1945.

Melalui observasi awal di SMP Murni 1 Surakarta, didapatkan kasuskasus pelanggaran terhadap tata tertib sekolah secara terus menerus seperti banyaknya peserta didik yang membolos, tidak megikuti upacara wajib di hari Senin, dan berseragam tidak sesuai dengan aturan tata tertib. Hal tersebut diakui oleh guru PPKn di SMP Murni 1 Surakarta dan hukuman yang diberikan kepada peserta didik belum bisa menimbulkan efek jera meskipun sudah melibatkan guru BK. Guru BK juga mengakui bahwa masih ada pesera didik yang mempunyai perilaku yang kurang sopan terhadap guru dan malas untuk belajar. Menurut peneliti, dari pemaparan guru PPKn tersebut juga menunjukkan bahwa pembelajaran PPKn masih terasa membosankan dan belum melaksanakan misi uamanya. Pembelajaran semacam ini, malah menimbulkan dampak pembelajaran yang bertentangan dengan pendidikan karakter yang seharusnya diajarkan, terutama di pembelajaran PPKn.

Masih berdasarkan hasil observasi, guru BK juga memaparkan bahwa peserta didiknya memang banyak yang berasal dari keluarga yang tidak kondusif seperti broken home, orangtua yang emosional, keadaan ekonomi keluarga, dan seringnya mendengar kedua orang tua mereka bertengkar. Meskipun tidak semuanya, namun dengan kurangnya perhatian orang tua terhadap tumbuh 
kembang anaknya menyebabkan kondisi psikologis anak terganggu. Hal tersebut menjadi salah satu penyebab meskipun sudah ditanamkan pendidikan karakter di sekolah, sikap peserta didik masih labil dan membutuhkan proses untuk menjadi peserta didik yang berkarakter baik di lingkungan sekolah maupun di luar lingkungan sekolah.

Peran guru dan pembelajaran menjadi sangat penting terutama dalam pembelajaran PPKn sebagai bentuk penguatan karakter kewarganegaraan agar peserta didik di SMP Murni 1 Surakarta menjadi pribadi yang mempunyai karakter kewarganegaraan yang baik. Apalagi di dalam berkehidupan bermasyarakat, dengan budayanya yang masih belum mendukung terciptanya pola hidup yang berkarakter, peran penting dari pendidikan menjadi sangat dibutuhkan. Ditujukkan dengan banyaknya kasus kejahatan, kenakalan remaja, dan yang sangat mencolok yakni pelanggaran terhadap lalu lintas.

Berdasarkan di atas, masih banyak ditemukan permasalahan mengenai pelanggaran tata tertib secara terus menerus yang mencerminkan bahwa pendidikan karakter di lingkungan pendidikan masih bisa diperbaiki agar mewujudkan terbentuknya karakter kewarganegeraan. Oleh karena itu, peneliti akan melakukan penelitian terkait hal tersebut di tingkat sekolah menengah pertama yang objeknya adalah SMP Murni 1 Surakarta. Peneliti akan mengkaji penguatan karakter kewarganegaraan dalam pembelajaran PPKn.

\section{METODE PENELITIAN}

Lokasi penelitian adalah SMP Murni 1 Surakarta dengan alamat Jl. Dr. Wahidin No. 33, Penumping, Laweyan, Surakarta. "Penelitian ini merupakan penelitian kualitatif dengan pendekatan penelitian menggunakan pendekatan deskriptif' karena tidak untuk menguji hipotesis melainkan membuat gambaran atau deskriptif tentang penguatan karakter kewarganegaraan di SMP Murni 1 Surakarta dalam pembelajaran PPKn. "Teknik pengambilan sampel yang digunakan adalah purposive sampling karena objek penelitian sudah ditentukan" terlebih dahulu di dalam penelitian ini yaitu SMP Murni 1 Surakarta. Objek yang dimaksud dalam SMP Murni 1 Surakarta yaitu 2 orang guru mata pelajaran PPKn kelas IX dan kelas VIII serta 10 peserta didik yang terdiri dari 5 orang kelas IX dan 5 orang kelas VIII. "Teknik pengumpulan data menggunakan wawancara, observasi dan dokumentasi dengan sumber data yang di validitas dengan teknik triangulasi data dan metode". Kemudian, penelitian ini di analisis melalui 3 tahap yaitu reduksi data, penyajian data dan verifikasi. 
HASIL PENELITIAN DAN PEMBAHASAN

\section{Implementasi Penguatan Karakter Kewarganegaraan di SMP Murni 1 Surakarta melalui Pembelajaran PPKn}

Berdasarkan hasil dari temuan peneliti, implementasi penguatan karakter kewarganegaraan di SMP Murni 1 Surakarta dilakukan melalui 3 cara yaitu:

1. Merancang RPP dengan memasukkan nilai-nilai karakter dalam pembelajaran PPKn sebagai bentuk penguatan karakter,

2. Melakukan penguatan verbal dan non verbal baik dalam pembelajaran di kelas maupun di luar kelas,

3. Melakukan home visit untuk melihat lingkungan sekitar peserta didik.

Pertama, merancang RPP dengan memasukkan nilai-nilai karakter dalam pembelajaran PPKn sebagai bentuk penguatan karakter. Dalam proses pembelajaran, karakter kewarganegaraan dapat terasah melalui Rancangan Pelaksanaan Pembelajaran (RPP) yang sudah dirancang oleh guru untuk Kegiatan Belajar Mengajar (KBM). Di dalam RPP yang sudah dirancang guru, sudah terdapat indikator-indikator yang harus mampu peserta didik capai. Indikator tersebut termuat dalam setiap kompetensi yaitu kompetensi spiritual, kompetensi sosial dan kompetensi pengetahuan.
Guru menuliskan indikator yaitu "Menunjukkan sikap beriman dan bertaqwa dalam pembelajaran perwujudan nilai-nilai Pancasila sesuai perkembangan zaman dalam berbagai kehidupan." Dari indikator tersebut, tujuan yang ingin dicapai yaitu peserta didiknya mampu menunjukkan sikap beriman dan bertaqwa.

Kemudian, di dalam kompetensi sosial guru menuliskan "Menunjukkan sikap jujur ...", "Menunjukkan sikap tanggung jawab ...", "Menunjukkan sikap percaya diri...". Dari indikator tersebut, tujuan yang ingin dicapai yaitu peserta didiknya mampu menunjukkan sikap jujur, tanggungjawab, dan percaya diri. Terakhir, dalam kompetensi pengetahuan guru menuliskan "Menampilkan perilaku perwujudan nilai-nilai Pancasila dalam kehidupan sehari-hari". Dari indikator tersebut, tujuan yang ingin dicapai guru yaitu peserta didiknya mampu berperilaku sesuai dengan nilainilai Pancasila sebagai perwujudan dari pembeajaran yang sudah diberikan.

Indikator yang dibuat oleh guru di atas sudah sesuai dengan ketentuan perumusan indikator menurut Permendiknas No. 41 Tahun 2007 yaitu:

1. Indikator dirumuskan dari $\mathrm{KD}$, indikator yang 
dirumuskan guru diturunkan dari KD yang sudah sesuai SKL

2. Menggunakan KKO yang dapat diukur, indikator yang dirumuskan guru sudah menggunakan KKO yang dapat diukur yaitu menunjukkan sikap dan menampilkan perilaku

3. "Dirumuskan dalam kalimat simpel, jelas dan mudah dipahami

4. Tidak menggunakan kata bermakna ganda

5. Hanya mengandung satu tindakan, indikator yang dirumuskan guru mengandung satu tindakan" yaitu jujur, tanggungjawab, percaya diri

6. "Memperhatikan karakteristik mata pelajaran, potensi dan kebutuhan peserta didik, sekolah, masyarakat dan lingkungan/daerah"

Nilai-nilai yang terkandung di dalam indikator yang telah guru rancang, tertuang juga di dalam silabus guru di bagian penilaian karakter, yaitu:

1. Religius

2. Santun

3. Tanggungjawab

4. Kedisiplinan

5. Kerja keras

Hal tersebut di atas juga merupakan cara guru untuk mendorong partisipasi aktif peserta didik dalam proses pembelajaran. Selain itu, indikator yang dirancang guru di dalam RPP juga ditujukan untuk memberikan umpan balik dan tindak lanjut bagi peserta didik. Hal ini sesuai dengan prinsip RPP (Suhana, 2012: 120), yaitu:

1. "Mendorong partisipasi aktif peserta didik, karena RPP dirancang untuk mendorong motivasi, minat, aktivitas, inisiatif, inspirasi, kemandirian dan semangat belajar"

2. "Memberikan umpan balik dan tindak lanjut, yaitu di dalam RPP memuat rancangan program pemberian umpan balik positif, penguatan, pengayaan dan remedi”

Kedua, dengan melakukan penguatan verbal dan non verbal baik dalam pembelajaran di kelas maupun di luar kelas. Guru sudah melakukan penguatan baik dalam verbal maupun non verbal. Hal itu tercermin dari bagaimana guru memperhatikan peserta didiknya ketika pembelajaran PPKn berlangsung. Pada saat pembelajaran, Guru selalu memasukkan nilai-nilai karakter yang baik dan apabila peserta didiknya dirasa bersikap tidak sesuai dengan peraturan maka guru dengan sabar selalu menasihati berulang-ulang agar peserta didiknya tersadar bahwa itu perbuatan yang kurang baik. 
Seperti pada saat peserta didiknya maju ke depan kelas untuk melafalkan Pancasila, di akhir peserta didik itu selesai guru memberikan apresiasi sebagai penguatan dengan mengucapkan kata "Bagus" sambil guru mengacungkan jempol. Kemudian, pada saat meminta bantuan kepada peserta didik, guru tidak lupa mengucapkan terimaksih. Di dalam hal tersebut, terdapat makna bahwa guru ingin peserta didiknya mengetahui bagaimana cara menghormati orang lain dengan hal-hal kecil. Sedangkan penguatan non verbal yaitu ditunjukkan dengan mendekati tempat duduk peserta didik yang tertidur agar bangun dan mengikuti pembelajaran kembali

Dari bukti di atas, penguatan yang dilakukan guru kepada peserta didiknya memang betulbetul dilakukan untuk mencapai tujuan agar peserta didiknya mempunyai karakter kewarganegaraan yang baik. Dampaknya yaitu perubahan perilaku mereka yang menjadi lebih baik, semangat mereka untuk belajar, dan mereka selalu merasa diperhatikan dengan cara penguatan tersebut. Hal ini sesuai dengan tujuan dari pemberian penguatan (Surwarna, 2002: 77), yaitu:
1) Meningkatkan perhatian peserta didik pada pelajaran

2) Meningkatkan motivasi berlajar peserta didik

3) Memudahkan peserta didik untuk belajar

4) "Mengeliminir tingkah laku peserta didik yang negatif dan membina tingkah laku positif peserta didik".

Sesuai dengan hal di atas, penguatan yang dilakukan oleh guru mampu meningkatkan perhatian peserta didik pada materi dalam pelajaran PPKn. Terbukti pada saat peneliti mengikuti kegiatan belajar mengajar, pada kondisi kelas ramai guru langsung menegur kemudian mereka kembali memperhatikan pembelajaran. Ketika kelas ramai kembali, guru diam terlebih dahulu sampai kondisi kelas tenang kemudian menasihati. Selain itu, penguatan tersebut juga mampu meningkatkan motivasi belajar peserta didik di dalam kelas. Hal tersebut dibuktikan pada saat peserta didik maju ke depan kelas satu persatu untuk melafalkan Pancasila. Pembelajaran PPKn di pertemuan sebelumnya, peserta didik yang belum hafal bunyi Pancasila menjadi lancar melafalkan Pancasila di pertemuan pada saat peneliti mengikuti KBM. 
Kemudian yang paling utama dari pemberian penguatan tersebut adalah dapat befungsi untuk meningkatkan kualitas tingkah laku seseorang dan dapat mendorong munculnya peningkatan kualitas tingkah laku tersebut di saat yang lain (Majid, 2013: 237). Hal ini tercermin dari bagaimana cara peserta didik berseragam, disiplin waktu dan cara berkomunikasi. Semua hal tersebut terbukti di SMP Murni 1 Surakarta terutama pada pembelajaran PPKn di Kelas IX dan VIII bahwa penguatan yang dilakukan oleh guru mampu menguatkan karakter kewarganegaraan mereka.

Ketiga, Melakukan home visit untuk melihat lingkungan sekitar tempat tinggal peserta didik. Guru PPKn di SMP Murni 1 Surakarta tidak memungkiri bahwa peserta didiknya banyak yang berasal dari lingkungan yang kurang baik bahkan orang tua nya pun terkesan tidak peduli dengan perkembangannya. Untuk meminimalisir tingkah laku peserta didik agar tidak terpengaruh oleh lingkungan mereka, hal yang dilakukan yaitu dengan melakukan home visit. Guru melakukan home visit kepada peserta didik yang sudah dalam tahap peringatan tertulis, peserta didik yang jarang masuk sekolah dan peserta didik dengan kondisi lingkungan yang tidak baik. Informasi pertama, guru dapat dari Guru BK terlebih dahulu karena catatan permasalahan peserta didik lengkap di Guru BK. Tujuan dari home visit ini yaitu menemui peserta didik di rumahnya untuk diajak berkomunikasi mengenai permasalahan yang dihadapi. Selain itu, home visit juga untuk menemui kedua orang tua agar guru mengetahui seberapa jauh orang tua mendukung anaknya dalam pendidikan. Kemudian, tujuan lain dari home visit ini adalah untuk mengetahui seberapa jauh efek pengaruh negatif kepada peserta didik dari lingkungan tempat tinggalnya untuk kemudian di berikan penguatan yang berbeda.

Home visit dilakukan guru untuk lebih meyakinkan peserta didiknya bahwa mereka sangat memperhatikan peserta didiknya agar menjadi individu yang berkarakter kewarganegaran yang baik. Home visit ini merupakan sebuah prinsip dari penguatan yang variatif karena dapat menyasar tidak hanya perseorangan namun juga kelompok. Perseorangan disini yaitu peserta didik itu sendiri, sedangkan kelompok yaitu keluarga dan kerabat. Hal tersebut sesuai dengan prinsip dalam pemberian penguatan yang diungkapkan oleh (Suwarna, 
2002: 78), antara lain sebagai berikut:

1) Kehangatan dan antusias

2) Kebermaknaan

3) Menghindari respons yang negatif

4) Penguatan pada perseorangan

5) Penguatan pada kelompok

6) Penguatan yang diberikan segera

7) Penguatan yang diberikan secara variatif

Pendidik yang berkarakter, berarti ia memiliki kepribadian yang mencerminkan moral yang baik, "seperti sifat kejujuran, komitmen, ataupun sifat-sifat lain yang harus melekat pada pribadi pendidik. Pendidik yang berkarakter kuat tidak hanya memiliki kemampuan mengajar dalam arti sempit (hanya mentransfer pengetahuan/ilmu kepada peserta didik) melainkan ia juga memiliki kemampuan mendidik dalam arti luas". Mengajar dalam arti luas ini, menjadi satu tantangan bagi guru untuk membuat peserta didiknya mempunyai karakter kewarganegaraan yang baik. Dengan peserta didik memiliki karakter kewarganegaraan yang baik, maka dengan perlahan akan mematuhi segala aturan-aturan yang berlaku di lingkungan sekolah dan mampu mengendalikan dirinya sendiri dengan hal yang baik maupun hal buruk.

\section{Hambatan dalam Proses Penguatan Karakter Kewarganegaraan melalui Pembelajaran PPKn di SMP Murni 1 Surakarta}

Terdapat hambatan yang dihadapi oleh Informan I dan Informan II dalam melakukan penguatan karakter kewarganegaraan di SMP Murni 1 Surakarta melalui pembelajaran PPKn. Hambatan tersebut, yaitu:

1. Tidak adanya dukungan dari orang tua, yaitu orang tua yang terkesan tidak memperdulikan bagaimana perkembangan peserta didik.

2. Faktor ekonomi keluarga, yaitu tidak terpenuhinya kebutuhan sehari-hari karena pekerjaan yang tidak tetap dari orang tua dan terkesan bekerja serabutan.

3. Lingkungan tempat tinggal peserta didik, yaitu besarnya pengaruh sikap menyimpang dalam kehidupan sehari-hari ke peserta didik karena berada di lingkungan yang ditinggali oleh orang-orang dengan lingkungan yang kurang baik seperti main judi, minum minuman keras dan tinggal di lingkungan kumuh.

4. Peserta didik yang tidak kondusif, yaitu seringnya ramai di kelas sehingga tidak 
memperhatikan apa yang dipelajari karena waktu kegiatan belajar mengajar habis untuk menegur dan menasehati.

Dari empat faktor hambatan yang peneliti temukan di SMP Murni 1 Surakarta, sejalan dengan hasil penelitian Novi Anggraini (2012:117-118) yang juga melakukan penelitian mengenai karakter kewarganegaraan pada pembelajaran PPKn di SMP SeKecamatan Parakan Kabupaten Temanggung yang menunjukkan hasil bahwa faktor terpenting dari pendidikan karakter adalah faktor dari lingkungan itu sendiri baik lingkungan sekolah maupun lingkungan tempat tinggal. Di dalam penelitiannya, hambatan yang ditemukan juga berasal dari lingkungan keluarga yaitu kurangnya perhatian dari orang sekitar terhadap perkembangan pribadi peserta didik, latar belakang sosial peserta didik, faktor ekonomi keluarga, lingkungan pergaulan peserta didik, dan pengaruh negatif teknologi yang tidak tersaring dengan baik.

Berdasarakan uraian di atas, hambatan yang dihadapi oleh guru menjadi tantangan bersama semua warga sekolah agar mereka terus melakukan penguatan terhadap peserta didiknya mengenai karakter kewarganegaraan dalam pembelajaran PPKn untuk mewujudkan peserta didiknya memiliki karakter kewarganegaraan yang baik.

\section{SIMPULAN DAN SARAN}

\section{A. Simpulan}

Berdasarkan data yang telah dikumpulkan oleh peneliti di lapangan serta telah dianalisis, maka dapat ditarik kesimpulan sebagai berikut:

1. Implementasi penguatan karakter kewarganegaraan di SMP Murni 1 Surakarta melalui pembelajaran PPKn, yaitu:

a. Merancang RPP dengan memasukkan nilai-nilai karakter dalam pembelajaran PPKn sebagai bentuk penguatan karakter. Nilai karakter ini akan tergambar melalui guru dalam merumuskan Indikator dimana semakin tinggi KKO yang dipilih, maka semakin tinggi pula tujuan pembelajaran yang akan dicapai.

b. Melakukan penguatan verbal dan non verbal baik dalam pembelajaran di kelas maupun di luar kelas. Peguatan yang dilakukan oleh guru ini, mampu memberikan efek positif bagi peserta didik dan 
efektiv dalam menjadikan peserta didik berperilaku yang lebih baik lagi. Penguatan verbal yang dilakukan guru antara lain dengan mengucapkan terimaksih dan memberi pujian atas apa yang sudah dilakukan peserta didik. Sedangkan penguatan non verbal guru yaitu dengan mendekati peserta didik yang sudah dinasihati akan tetapi masih belum sadar.

c. Melakukan home visit untuk melihat lingkungan sekitar peserta didik. Guru dalam melakukan home visit juga untuk memastikan bagaimana kondisi keluarga mereka dan lingkungan sekitar tempat tinggal.

2. Hambatan dalam proses penguatan karakter kewarganegaraan melalui pembelajaran PPKn di SMP Murni 1 Surakarta

a. Tidak adanya dukungan dari orang tua, yaitu orang tua yang terkesan tidak memperdulikan bagaimana perkembangan peserta didik. Tidak adanya dukungan juga dikarenakan pendidikan orang tua yang rendah sehingga dalam melakukan treatment kepada anaknya terkesan apa adanya.

b. Faktor ekonomi keluarga, yaitu tidak terpenuhinya kebutuhan sehari-hari karena pekerjaan yang tidak tetap dari orang tua dan terkesan bekerja serabutan. Hal ini akan membuat peserta didik mudah membangkang karena menginginkan hal yang lebih dari yang orang tua dapatkan atau berikan.

c. Lingkungan tempat tinggal peserta didik, yaitu besarnya pengaruh sikap menyimpang dalam kehidupan sehari-hari ke peserta didik karena berada di lingkungan yang ditinggali oleh orang-orang dengan lingkungan yang kurang baik seperti main judi, minum minuman keras dan tinggal di lingkungan kumuh.

d. Peserta didik yang tidak kondusif, yaitu seringnya ramai di kelas sehingga tidak memperhatikan apa yang dipelajari karena waktu kegiatan belajar mengajar habis untuk menegur dan menasehati.

\section{B. Saran}

Berdasarkan hasil dari simpulan dan implikasi dari penelitian ini, adapun saran yang diberikan yaitu, sebagai berikut:

1. Bagi Peserta Didik

a. Hendaknya peserta didik lebih memiliki pemahaman yang benar dan tepat 
mengenai karakter kewarganegaraan, sehingga dalam mewujudkannya tidak salah langkah.

b. Hendaknya peserta didik dapat membaca kondisi lingkungan untuk mendukung kegiatan pembelajaran yang berlangsung

2. Bagi Pendidik

a. Guru hendaknya dapat lebih tegas dalam memberikan teguran dan nasihat agar peserta didik menjadi jera melakkan hal-hal yang tidak sesuai dengan peraturan yang ada.

b. Guru dapat menggunakan media pendukung sebagai cara agar menarik minat peserta didik untuk lebih memperhatikan

pembelajaran agar tidak terkesan membosankan.

c. Guru meningkatkan lagi kompetensi sosial, kompetensi pedagogik, dan kompetensi pengetahuan dengan mengikuti diklat.

3. Bagi Sekolah
a. Seharusnya pihak

sekolah menjadikan home visit sebagai agenda rutin dan juga sering mengadakan kegiatan komunikasi dengan orang tua di sekolah. 
29 Faizah Nur Diana: penguatan karakter kewarganegaraa di SMP Murni 1 ...

\section{DAFTAR PUSTAKA}

Malik Tuanaya dkk. 2007. Modernisasi Pesantren. Jakarta: Balai Penelitian dan Pengembangan Agama Jakarta.

Sugiyono. 2012. Memahami penelitian kualitatif. Bandung : Alfa Beta . 2013. Metode penelitian kuantitatif, kualitatif, dan $R \& D$. Bandung : Alfa Beta.

Zubaedi. 2005. Pendidikan Berbasis Masyarakat. Yogyakarta: Pustaka Pelajar. 